\title{
Introducing the Gender Aspect into Hungarian IT Education $^{1}$
}

\author{
SZLÁVI Anna
}

\begin{abstract}
The IT sector has been rapidly growing; in fact, a high number of jobs are expected to remain unfilled, which makes it our common interest to attract more students to this field. The striking scarcity of women in the IT sector offers an obvious solution: if more women could be involved, the labor shortage in IT could be fixed. The low number of women in IT has strong ties with IT education; therefore, the role and responsibility of teachers is immense. If we want to have more workforce and more competent professionals in the IT sector, educators need to create a more hospitable environment for girls and women in (both secondary and tertiary) education. The present study aims to show why it is key to introduce the gender aspect into IT education, both globally and specifically in Hungary. The primary goal of the article, thus, is to call attention to the repercussions of entrenched gender stereotypes in education, while also offering specific methods that can make IT-related classes more inclusive.
\end{abstract}

Keywords: IT, IT education, STEM education, gender, stereotypes

\section{Introduction}

The IT sector has been on the rise. In fact, it has been predicted to grow by $7.6 \%$ by the end of 2020, which means that almost 800,000 vacancies will remain unfilled in Europe. [1] At the same time, only around $16.5 \%$ of ICT professionals are women in the EU28 zone according to the statistics of Eurostat, the European Commission's primary database, as of October 2019. In Hungary, the situation is particularly severe: the EC's statistics reveal that in 2018 women constituted only $9 \%$ of those employed in the sector, which is the lowest in the EU28 zone. [2] With a better involvement of women in the tech industry, the EU's - and particularly Hungary's GDP could be increased by millions of euros each year, EC concludes.

The present scarcity of women in IT has obvious ties with IT (and overall STEM) education. The stereotypes that link science to men, and thus, to boys, are revealed to be primary causes of women's, and girls', exclusion from fields connected to science. [3] According to Nosek et al.'s cross-national research, cultures that tie gender (specifically masculinity) to science discourage women to be accepted and perform well in STEM ${ }^{2}$. The role and responsibility of educators, therefore, is immense. If we want to have more workforce and more competent professionals in the IT sector, educators need to create a more hospitable environment for girls and women, both in (secondary and tertiary) education.

It has been declared that IT classes need to be diverse [4], interactive [5], and cooperative [6]. The present paper claims that this is not enough. IT classes, in addition, need to be sensitive to social identities and social stereotypes as well, including those connected to gender. It is vital that the educator considers not only the unique skills and competences of students, but also their cultural, ethnic, or gender identities, counterbalancing possibly harmful social stigmas. The present study, thus, aims to show why it is essential to introduce the gender aspect into IT education, both globally and specifically in Hungary. The primary goal of the article is to call attention to the repercussions of entrenched gender stereotypes in education. Revealing that the low representation of girls and women in IT is not only a theoretical problem but social and technological as well, the paper

\footnotetext{
1 Throughout the paper, "IT education" will be used as an umbrella term that refers both to secondary Informatics education and tertiary Computer Science education.

${ }^{2}$ STEM is the acronym of Science, Technology, Education, and Mathematics.

Central-European Journal of New Technologies in Research, Education and Practice

Volume 2, Number 2, 2020.
} 
pursues to offer specific methods and practices that can make IT-related classes more inclusive, thus involving more girls and women in the IT sector, specifically in Hungary.

\section{Theoretical background}

\subsection{The concept of gender}

In the past decades, numerous international and Hungarian researchers turned their attention to the issue of gender. [7,8,9,10] Various disciplines, such as linguistics [11], social sciences [12], psychology [13], and pedagogy [14], have revealed that gender inequality and discrimination is pervasive: globally women are at significant disadvantage, compared to men, in a number of areas of life. For example, girls are left out of the education system more often and/or earlier than boys due to child marriage, pregnancy, family duties, sanitation problems, or poverty, among others [14]. When growing up, women are less likely to work in well-paid positions, or when in the same position they are typically paid less than men. [15]

As for leadership and politics, women have a much lower representation worldwide than men (see [16]). Apart from education and empowerment, women are in a less advantageous position regarding safety as well: 1 in every 5 women is a victim of domestic violence, perpetrated by a male (see [17]). In addition, even after the assault happened, women get less than necessary protection: the discourse of trying rape and harassment cases still often involves victim-blaming. [18] In sum, women tend to lack equal opportunities regarding education, wealth, power, protection, and safety. It is so mainly because of mainstream ideology, based on binaries and gender stereotypes, which creates and maintains a gender-based hierarchy. [19]

As for the Hungarian context, the country has been part of the OECD since 1996 and the European Union since 2004; as such, Hungary is supposed to be among the most progressive communities in the world regarding human rights. If we look at the statistics, however, we are faced with a different reality. According to a recent worldwide survey [20], Hungary is among the 40 countries with the largest gender pay gap in the world, and among the 10 with the worst political representation for women. Both of these results place Hungary as one of the worst both within the OECD region and the EU concerning equal opportunities.

Patriarchal gender relations have a long history in Hungary [21]; thus, gender inequality is not a new phenomenon. Nevertheless, in the last decade gender equality became one of the most severe within the region. While in 2006 the country held the $55^{\text {th }}$ position on the above mentioned Global Gender Gap list, 10 years later Hungary doubled its score, positioning itself in the worst third. In other words, it is crucial to address gender inequality in Hungary, and particularly women's low representation in leadership and power, in order to be able to influence change. In her recent comprehensive study, Szlávi analyzed contemporary Hungarian discourses to reveal the depths of entrenched gender stereotypes, concluding that all main domains of popular communication, including language use, media, advertising, and even art are imbued with gender-based inequalities. [22]

\subsection{Gender in IT}

Both globally and locally, gender inequalities pose serious problems to our society. The IT sector, one of the economically most influential industries in the world, is no exception. Women are at a disadvantage even in this field. If we observe the highest level of the sector, we will find a low

Central-European Journal of New Technologies in Research, Education and Practice

Volume 2, Number 2, 2020. 
number of women in the management positions of the world's three most prominent IT companies; Apple, Microsoft, and Amazon. At Apple there are 4 women for 12 men, at Microsoft 3 women for 12 men, and at Amazon 6 women for 11 men (see apple.com, microsoft.com, aboutamazon.com).

Nevertheless, it is not only the management level that reflects severe inequalities, but it is the whole of the IT world. Kirkup's survey, studying the IT sector of the UK, the USA, Canada, Taiwan, Ireland, and Spain, uncovered both horizontal and vertical division of labor and inequalities within the sector. [15] The main finding of the research is that women are underrepresented in IT professions. For one, there are emphatically fewer women in the technical or engineering segments of the field; instead, they typically work in non-professional roles such as sales (horizontal inequality). For two, the women that do get employment in the IT sector are typically paid less and/or work in a lower status than their male colleagues (vertical inequality). For three, in certain countries it also appeared to be a trend that women that end up working in the sector have a higher degree than men. Finally, Kirkup's research revealed that not only employment but also advancement shows different patterns when it comes to gender: men are promoted faster than women even if their leadership skills are reported to be weak.

More and more scholars $[23,24,25]$ are turning their attention to the low representation of women in the field, which keeps raising awareness. Thanks to this, we can witness an increasing number of initiatives that attempt to turn the findings into a call for action, with the goal of enhancing the participation of girls and women in STEM fields. Besides the large-scale global projects ${ }^{3}$, we can list some initiatives that strive to ameliorate the acute inequality in these fields even in Hungary. As an example, see "Lányok napja", that is, 'Girls' Day' (http:/ / lanyoknapja.hu). "Lányok napja" is an annual nation-wide event dedicated to promoting the STEM sector for high school girls through diverse programs offered to them by universities and companies, that is, their potential places of education and employment. ${ }^{4}$

Overall, though, the attempts to involve a fair amount of girls in the field are limited in success. There are still just a handful of women in - well paid and / or influential - IT positions, which leads to a shortage of role models for the younger generations. Role models play a crucial role in inspiring students to pursue a certain field. When examining the impact of role models in the media about science, specifically mathematics, Lócska and Kovács concluded that the attitudes of high school students towards maths was positively affected by popular movies such as Hidden Figures [26]. The 2016 American film is (mainly) about the contributions of three African American women to NASA's aeronautical success. The movie not only portrays the STEM field in an attractive light but it also pays tribute to the role of women in the field. While such works of popular culture are undeniably inspirational, the scarcity of visible women role models in present-day IT poses a serious obstacle. Without approachable and living female role models, girls are left without the encouraging evidence that it is a woman's path too, thus few of them venture into the field. In addition, the discouraging or even hostile attitudes, of some men and boys, towards women that do get into IT remain unchallenged, making it hard for women to remain in the sector. In other words, the gender stereotypes that brought about, and keep on maintaining, the unequal situation, namely that women are not good at objectivity and logic, hence science, nor are they interested in such fields, remain unquestioned. [15]

\footnotetext{
${ }^{3}$ Some such projects are girlsintech.org, girlswhocode.com, and www.womenintechnology.org among others.

${ }^{4}$ Originally, Girls' Day is an European initiative dating back to 2000, which Hunary joined in 2012.
}

Central-European Journal of New Technologies in Research, Education and Practice

Volume 2, Number 2, 2020. 
It must be noted that the absence of women in IT is not just a matter of social injustice. Apart from the fact that the low representation of women in this well paid and highly prestigious profession makes the overall and pervasive gender gap even more serious, it also has tangible and concrete technical repercussions. Who makes the software, the program, and the algorithm influences the software, program, and algorithm itself. If women are typically only users, and not developers, of IT [27], the female perspective, or more broadly diversity, will be missing from the process of creation and development.

The lack (or scarcity) of women, or generally that of diversity, in the programming team poses problems in several domains of IT. To demonstrate this, let us observe a popular field of AI technology, that of facial recognition. Facial recognition, which uses machine learning, works properly if it operates in an accurate and unbiased way, which entails gender-neutrality as well. Yet, according to recent research done by MIT, most face recognition softwares (Microsoft, Face ++ , and IBM) fail to operate in an accurate, unbiased, and gender-neutral way. Buolamwini and Gebru pointed out that these softwares do not work with the same precision and efficiency when it comes to the faces of women, especially women of color, as they do with (white) men [28]. Their error rates of the above listed facial recognition systems were $23 \%, 36 \%$ and $33 \%$ (respectively) when recognizing black women's faces, while with white men there was hardly any error.

According to Buolamwini and Gebru, the training sets used in machine learning were not adequate: (gender and ethnic) diversity was underrepresented in the samples, and likely in the programming teams as well [28]. Buolamwini, furthermore, warns that stereotypes and biases - or invisibility that maintains lower social status - can easily get into the algorithms, thus into the programs as well, further promoting and reinforcing injustice. It is especially the case if the programming team is not diverse enough so the members could watch out for the blind spots, or the unconscious biases, of each other. [29]

Facial recognition systems are pervasive, as they can be used for a myriad of purposes. To mention their most widespread usage, it is worth noting that even smartphones are equipped with general face recognition software nowadays. But the same face recognition technology forms the basis of more specific applications as well; for example, emotion recognition programs, enabling people on the autism spectrum or people with visual disabilities, are built on this technology as well. In addition, crime prevention and policing also applies similarly trained facial recognition programs [28]. It is easy to see that if the basic face recognition algorithm is biased (regarding gender, ethnicity, or anything), it can have severe consequences in such situations; misidentifying a perpetrator is not a minor mistake, sometimes not even one that can be undone.

As the study about facial recognition shows, a diverse, inclusive, and cooperative developer team is undeniably vital. It is for a broader social good that gender-inclusivity and diversity must be put as a priority. In addition, business-focused research seems to suggest the same, only on different grounds. Frehill and McGrath Cohoon's investigation points out that diverse teams perform better and bring innovation [23]. Thus, they reiterate that it is not only for a social good but also for the economy that diversity should be addressed and enabled.

\subsection{Gender in IT Education}

It is clear that the involvement of women, just as other social groups, in IT is our common - social, economic, and technological - interest. To enhance gender balance in the field, IT education has a central role.

Central-European Journal of New Technologies in Research, Education and Practice

Volume 2, Number 2, 2020. 
According to Ramirez and Kwak's analysis of UNESCO's statistics about university enrollments between 1970 and 2010, women's participation in tertiary programs has been steadily rising all over the world [30]. In 2010, women comprised already 50-60\% of all enrolled students. As for STEM programs, however, the improvement was less significant: while there is some global progress regarding women's involvement, it is not as much as what we can see regarding women's overall presence at universities. In 2010 women still failed to constitute half of the students pursuing STEM majors; the numbers were stuck at 30-40\%. In Hungary, women's participation has always been lower; around $24 \%$. What is more, Hungary is one of the four countries, on the list of more than a hundred, where the participation of women in engineering and science majors not only failed to make a leap but it actually decreased during the past decades: from 24.7 to $23.1 \%$.

In 2012 a Hungarian technical university decided to conduct a large-scale survey in order to find out why Hungarian high school girls are reluctant to choose engineering majors [31]. As the main finding of the research it was concluded that girls decide to stay away from engineering/IT mainly because they had bad experiences in high school STEM classes. Many of the high school girls who were asked complained not only about the content of physics and maths (and other STEM) classes but also about the attitudes of their teachers. Some of the educators involved in the survey confirmed these negative stereotypes themselves by making generalizing statements such as girls are worse at science, girls are less smart, etc. In fact, a number of these teachers were aware of their tendency to treat students differently based on their gender.

The research was interested in uncovering girls' attitude towards IT as well. Some of the main findings include that girls labeled IT and engineering as "masculine" fields. They also added that in their opinion reconciling such careers with "feminine duties" such as family life was hard.

From the above statements it is apparent that gender roles as social constructions [8] have a great impact on the career choices of students. In other words, one of the key findings of the study was the connection of gender stereotypes with the low number of women in STEM. Whether educators feed or challenge such stereotypes largely determines what professions students can imagine suitable or appropriate for themselves. Therefore, if IT teachers strived to create genderneutral environments, or ones which openly defy social stereotypes, it could positively affect the career choices of their female students, while also sensitizing male students.

\section{Gender-Inclusive Practices in IT Education: A Case Study}

\subsection{Background}

After identifying the problem, it is crucial to discover what we can do to mend gender imbalance in IT education. According to Bonder, there have been three different approaches to deal with the issue, which are: "to fix the numbers," "to fix the institutions," or "to fix the knowledge." [32]

The first approach entails that we focus on the very result; that is, after acknowledging the problem that there are few women in IT programs, we attempt to simply increase their presence in the student body. Even if achieved, this, however, does not guarantee that the change will be sustainable. Mainly so because the infrastructures of the institutions will remain unchanged; that is, still more adapted to men and more challenging for women (to name some of such elements: the

\footnotetext{
${ }^{5}$ To read a more detailed analysis of the research, check [33].

Central-European Journal of New Technologies in Research, Education and Practice

Volume 2, Number 2, 2020.
} 
overwhelming majority of male instructors, the advancement inequalities, or the lack of facilities that would enable women with young children to complete a program).

Realizing that only some of women's challenges can be mended simply by adding more female students into the institutions, the second approach, "to fix the institutions," turns to overcoming the institutional barriers that keep women away from the majors and the field. Thus, this approach focuses not only on the result but also on some of the reasons that brought about those results (for example, by creating nursing rooms for women with children). Unfortunately, however, even this approach fails to address the roots of the problem, the social conception of structured gender inequality, which jeopardizes a long term success.

The third approach, which proposes the concept of "fixing the knowledge" in order to mend women's scarcity in IT, tries to go to the root of the problem. According to this idea, only if we educate people about gender balance starting as early as in school can we bring about sustainable change. How an educator can make inclusive IT classes is not an easy question, though. In the following, we will go through some of the main theoretical concepts, then a case study will demonstrate one of the possible ways they can be put into practice.

It is emphatically important how educators in primary and secondary schools approach their classes, as students are still in the phase when they can decide for or against pursuing an IT career. For a primary or secondary school teacher, therefore, it is crucial to be aware of the gender stereotypes related to their field, along with their potential impact. To do that, they first of all need self-reflection, as Lipovits et al. point out [34]. In addition, tolerance, open communication, equity, fairness, and social sensitivity [34] are also crucial, not only for enhancing gender balance but also to create versatile, diverse, and cooperative working groups.

Next to the educator's attitude, teaching methods have a central role as well. A diverse student group can be motivated and inspired by diverse tasks [15]. In other words, presenting from multiple angles what IT is capable of is more likely to engage students and reveal the true potential of technology (and a career in technology). It is also necessary to realize that solving tasks in pairs or in groups, that is, in cooperation, makes the learning process more effective [6] and more motivating. Additionally, the content of the tasks should also be chosen consciously: multicultural study materials can be inspiring and at times even liberating. Kátai suggests the use of training materials with ethnic and cultural content [35]; in a similar vein gender diversity could also be an important element of our materials.

In summary, it is an essential goal, and actually a requirement, of 21 st century educators of primary and secondary schools to help girls become creators, not only users, of technology. It should be a conscious aim to present not only why IT is exciting and useful, but also that it is an available career path for girls (too). As a consequence, raising students' awareness of role models and success stories related to women in IT can make the field more attractive and more widely chosen.

University educators have much fewer students to help thrive in or deter from IT careers, yet their role and responsibility cannot be underestimated. Their task is not primarily to raise interest but more to keep students in the field and to educate them to become conscious, socially sensitive, and inclusive IT professionals. In order to do this, Margolis and Fisher claim that it is essential to humanize and contextualize programming [36]. What this means is that university educators need to demonstrate the social aspects of IT, on the one hand, and to connect it with various fields and disciplines, on the other. Next to these principles, the authors consider teamwork and cooperation to be the methodological pillars of inclusive tertiary IT education. It is so because such settings can encourage tolerance and inclusion to be at the core of the programming process. Finally, the authors underscore the importance of providing female students with role models, which can be

Central-European Journal of New Technologies in Research, Education and Practice

Volume 2, Number 2, 2020. 
done through mentorship programs in which students are teamed up with female scholars or professionals. [36]

\subsection{Case Study}

The following case study from the author's own teaching practice is to demonstrate how an ITrelated course can be put together using methods that support gender-inclusivity and diversity. First the setting of the course will be explained, then the material and methodology will be detailed.

In 2018 a new, four-semester-long Computer Science (CS) program was launched at the Faculty of Informatics at Eötvös Loránd University, Budapest. In the frames of the program, students are expected to learn and practice professional English language use, not just programming, given that most of the CS literature is in English. The two-semester-long language course, scheduled for the first two terms of the program, is compulsory; that is, all students take part in it and, what is more, at a crucial time of their studies. Depending on the current enrollment, the groups of the course are made up of 12-18 students; in 2018/2019 that meant 2 groups, while in 2019/2020 there were 4 of them. The present case study is intended to introduce this course, running for two years now.

The course, whose purpose is to acquaint students with CS topics and materials in English from around the world and make them engage in discussions related to IT, is not an IT class strictly speaking, at least not one about hard skills. Despite this, the principles and practices that will be presented are useful and usable in hard skills, programming courses as well. For one, because the course is in fact very tightly connected to IT, as its primary goal is to bring IT topics closer to and more accessible for CS students early in their studies. For two, because the principles and the methods that underlie this course are general, thus transferrable to other types of classes.

For designing the course, Margolis and Fisher's recommendations [36] served as methodological tools. In order for IT classes to be efficient, the authors underline the importance of using teamwork and cooperation when solving tasks; humanizing and contextualizing programming; and presenting role models as part of the study material. The specific circumstances of the course also had to be taken into consideration. There were two factors that emphatically called for the application of Margolis and Fisher's tools: on the one hand, the large number of students, with different competence levels, within a group made it impossible to plan a lot of - undifferentiated - frontal classwork. Instead, group and pair work seemed to be more suitable as that way students could and were forced to help and complement each other while solving tasks together. On the other hand, as the student body was (and has been) overwhelmingly homogeneous regarding gender and ethnicity (the majority has been white, male, and Hungarian), it was also obvious that diversity, difference, and inclusion had to be brought into the class through the study materials. Altogether, both with the methods (of differentiated education and teamwork) and the contents (of diverse materials and contextualized tasks), the course was aimed to improve students' cooperational and social skills, in order to make them better language users, but also better programmers.

As for the content of the course, it was designed primarily to demonstrate the human side, the social context, and the diversity of IT to students who are interested but may not yet be deeply experienced in IT. The course was divided into two parts (semesters) in a way that the materials did not only connect to but also derived from each other. While the first part was supposed to build the foundations of the coursework, the second was meant to elaborate on and deepen the concepts and the skills. All the communication, skills development, or analytic activities of the

Central-European Journal of New Technologies in Research, Education and Practice

Volume 2, Number 2, 2020. 
course were based on eight, high-quality, English-language TED-talks ${ }^{6}$ covering a specific IT topic. They are the following:

- Agüera y Arcas, Blaise: How PhotoSynth can connect the world's images

- Arar, Raphael: How we can teach computers to make sense of our emotions

- Bracy, Catherine: Why good hackers make good citizens

- Buolamwini, Joy: How I'm fighting bias in algorithms

- Feinberg, Danielle: The magic ingredient that brings Pixar movies to life

- el Kaliouby, Rana: This app knows how you feel - from the look on your face

- Lupi, Giorgia: How we can find ourselves in data

- Redmon, Joseph: How computers learn to recognize objects instantly

In the middle of the coursework and at the very end of it, students were asked to do self-reflection related to the course material. Both in graded and ungraded frameworks, they were asked to share their opinions on ideas such as "cooperation," "social responsibility," "tech values," and "role models" in the connection of the analyzed tech talks, and generally IT.

\subsection{Discussion}

The course material was compiled in order to reflect and emphasize the diversity, the rich variety of contexts, and the human aspects of IT, so students can more easily find themselves in and connect with CS.

As one of the guiding concepts of the course, diversity appeared in the material on several levels. First of all, the speakers were selected so they can represent and present different subtopics within IT in order to showcase the wide options within the field. Next to expertise, the identity of the speakers were also meant to be a testament of difference (and inclusion). Regarding their ethnicity and origins, the speakers are not at all homogenous: there are white and black tech experts; European, American, and African IT professionals. Religion and sexual orientation appear as a matter of choice as well. Finally, as far as gender is concerned, it was a very conscious decision to include a fair number of women among the presenters. Five of the eight speakers are women (C. Bracy, J. Buolamwini, D. Feinberg, R. el Kaliouby, and G. Lupi), as figure 1 shows. With this, the course aimed to clearly demonstrate, both to the few female students and to the masses of male students, that women also have a place in IT. By watching such role models speak, students could realize that women can be authentic, inspirational leaders and experts of IT as well. Altogether, the course material was designed to make (both male, female, and non-binary) students conscious of the fact that IT is, and has to be, a diverse field, in the gender aspect and many others.

\footnotetext{
${ }^{6}$ TED (www.ted.com) is a series of conferences mainly about Technology, Education, and Design (hence the acronym), whose high-quality and mainly English-language talks are freely accessible on their website. For most of the talks, subtitles and transcripts are also available, which makes them not only thought-provoking professional presentations but also easy to use language learning materials.
}

Central-European Journal of New Technologies in Research, Education and Practice

Volume 2, Number 2, 2020. 

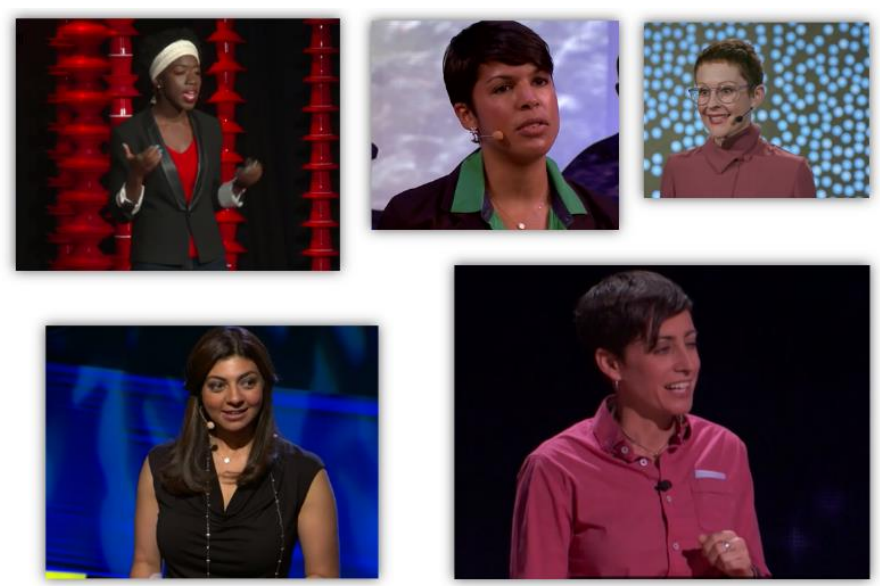

Figure 1. The female presenters of the IT-related TED talks used in the course

As Margolis and Fisher emphasize, it is also essential to contextualize IT [36]. As it was mentioned before, all the talks present a specific and different area within technology, such as computer vision, object recognition, animation, data visualization, and so on. Each of them place their respective technology within a specific context, offering insight into what can be done with coding. To give an example, one of the speakers (el Kaliouby) demonstrated in her talk that machine learning can be used for the development of emotion-enabled apps which can facilitate emotion recognition.

Besides giving context to IT, it was also an important goal to humanize it. Even in this aspect all the selected talks fare well: each of the speakers stress the importance of social responsibility when putting their specific technology to practice. To demonstrate this, it is best to continue elaborating on the previously mentioned video. When talking about her company that works with emotion recognition, el Kaliouby was quick to emphasize the social relevance of such technology. She explained that an emotion enabling app can not only help people who are visually impaired or are on the autism spectrum decode emotions, it can also assist all of us to communicate and connect better with our tools and each other. The fact that every speaker approached their topic in a similar matter, not failing to mention the social importance of their projects, students could become aware that social responsibility is key in IT, even if this aspect is rarely addressed during their CS studies.

In order to check the effectiveness of the methodology, students were asked to reflect on various concepts, core to the course, multiple times. Both at the end of the first term and at the end of the second term, in practice and in test situations they had to contemplate on (1) what they think about cooperation and teamwork, (2) what they consider to be the main social values in IT, and (3) who they were inspired by. This way, the course not only offers them situations to practice the values Margolis and Fisher define to be effective learning tools, such as groupwork, the humanization and contextualization of IT, and role models, but it also makes them become conscious of them.

A selection of students' short self-reflective essays is found in the Appendix. Three of the main topics are listed: in Appendix 1 their opinion about collaboration, in general and in IT in particular, is summarized; in Appendix 2 their stance on social values and tech values is detailed; and Appendix 3 lists their confessions about their role models as future IT experts. ${ }^{7}$ Going through the entries in Appendix 1, we can see that students believe that cooperation is crucial not only for efficiency and swiftness, but also because team members can complement each other and produce more diverse

\footnotetext{
${ }^{7}$ The excerpts were not categorized according to the students' gender, for one, because sensitivity about the gender-inclusiveness of IT is desired from both (or all) genders; for two, because students were not asked to specify their gender during the course. The selection aimed to highlight the diversity of their responses, thus avoiding the binary bias of gender stereotypes.
}

Central-European Journal of New Technologies in Research, Education and Practice

Volume 2, Number 2, 2020. 
and socially more inclusive solutions. As for values in IT, students listed equality, inclusiveness, diversity, and lack of discrimination. Some of them even addressed that it is their responsibility as future programmers to respect and enforce these values. Finally, when students were asked which speaker inspired them throughout the course, they responded in a lengthy and passionate way. It is also worth noting that several speakers were named, not just one, which shows that the diversity of people can be inspired by the diversity in the course material (Appendix 3). It is worth noting that multiple students underlined that they could relate to the personal stories (often about initial struggles) of the speakers and that seeing them succeed gave them hope that they would too. Especially female students seemed to verbalize such impressions.

In sum, with the course I have made a conscious attempt to place IT in a setting that embraces diversity, overcomes stereotypes, and celebrates social responsibility, both with its choice of content and methodology. Besides enforcing the general idea of diversity, the course specifically strived to provide support and inspiration for female students, through the presentation of female role models and the discussion of equity and equality in IT, so that they persist and thrive in the IT field.

\section{Conclusions}

The goal of the present paper was to explain why it is important to approach IT education from a gender perspective. Due to social stereotypes infiltrating classrooms (as well), girls and women are gravely underrepresented in the IT sector, which has serious social, economic, and technological ramifications. The role of IT educators is huge in this process. By questioning entrenched gender stereotypes related to IT (and STEM in general), along with enabling diversity and cooperation within the classroom, teachers can have a beneficial impact on the gender balance in the IT world. The second half of the paper aimed to give some practical guidance about how this can be done. The case study of a recent, and as a matter of fact ongoing, IT(-related) course of the author's was meant to show how the notions of cooperation in classwork, the contextualization and humanization of the IT topics, and the presentation of role models can be implemented to overcome gender stereotypes and celebrate diversity.

\section{Acknowledgements}

The author wishes to say thanks to Zsuzsa Kecskés, Amy Soto, Péter Szlávi, and Ráhel Turai for their invaluable contribution to the paper.

\section{Appendices $^{8}$}

\section{Appendix 1: Collaboration}

1) "I think collaboration in general is important because people have different abilities and talent. If they work together, anyone can add something. By this they can create a better result. On the other hand, it's important because teammembers came in different environment. They have diverse thoughts, feelings, ideas. And because of that, they can reduce prejudice and bias."

\footnotetext{
${ }^{8}$ The essays were not corrected or modified for the sake of authenticity.

Central-European Journal of New Technologies in Research, Education and Practice 
2) "We need to unite as people to accomplish far greater things than before. It would be faster, more efficent. I personally feel more happy if I could see bigger and better collaborations with time."

3) "I think collaboration is important because we all have different ideas and opinions. By working together we can assure that the final product of our work will reflect us all. Collaboration is specially inportant in programming, because usually a person only works on a specific part of the project, so we should be able to work together in order to finalize the project successfully. Based on the Civic Hackers video, and also based on real life experiences, when people work together for one common goal, they are more successful than as individals. If a lot of people join togheter, they can make real changes in the world."

4) "In my oppinion, collaboration is the most important thing in life. Also, if you collaborate with others, you can get other ideas, other visions about a thing. In Civic Hackers, they involved everyone. In class, we devided the task and everyone worked alone on a part, and then we discussed the whole thing. I think this is one is a better way of collaboration."

\section{Appendix 2: Values}

1) "There are some issues, that we have to fight against: neutrality, privacy protections, and internet acces (for not everyone)."

2) "Some tech values would be inclusiveness and diversity, so the technology can be accessed and used by the widest possible audiences, without discrimination."

3) "As we get more and more dependent on digital technology, it is clear, that programmers and software developers have way more power, but also more responsibilities. We/they have to recognize this, otherwise they can contribute to bad practices such as racial discrimination as we seen in the algorithmic bias video. However, the same power can also be used for benefiting society (as we seen in the civic hackers video). Developers have to have values in mind when innovating, to keep technology easily accessible and also beneficial for all people."

4) "Tech must serve everyone in an equal way, nobody should be discriminated by tech. Tech should focus on people and it must connect them together not separate them. Tech is should be more personal and it don't have to be cold."

\section{Appendix 3: Inspiration}

1) "I found Danielle Feinberg and her talk about her work at Pixar very interesting, and inspiring. How she struggled with her future plans, and found her way to the work she does now was familiar to me. And the way she described how the computer science and programming knowledge she learned could be used to express her artistic desire and passion was truly heartwarming and inspiring."

2) "One of my inspirations was the girl who talked about algorythmic bias. Before I saw that video I havent thought about this problem before, but after viewing that video, I just thought that this should get more attention."

3) "I liked the presenter who talked us about civic hacking the most, because she showed us a new way to participate in activities, which can help for every member of the society, and many small acts can solve huge problems of the government."

Central-European Journal of New Technologies in Research, Education and Practice 
4) "Personally, I found the Pixar movie video the most inspiring. I can relate to the talker being interested in art and programming simultaneously, and her desire in wanting to conbine them. At the moment I am learning animation and film making, and I also have a sertificate in photography. By learning programming I can widen my future possibilities at pursuing a carrier. It can help me create my own website for my portfolio. And maybe later I will learn to make computer games by combining my artistic and programming skills. To see someone who have already done that and has been successfull, gives me hope for the future."

5) "The one who had the biggest effect on me was clearly Catherine Bracy. She showed how action of the everyday people can make a big difference. She presented many interesting examples, where people stood up for themselves, made better systems for their own good and contributed to public services. Sometimes it just seems like people are not willing to sacrifice the time and energy to make change, they only complain, and wait for the change to come form above. However, she showed us that if the platform is set up (like the Oklahoma "write-a-thon" or the challenge issued in Mexico city) people are happy to contribute. As a future programmer, this infected me with new ideas about how I could make such "platforms" in the future, and how to get people involved."

6) "I was inspired the most by the Pixar women. She and her childhood dream gave me a push that I needed in programming. I love to draw too, just like programming, and according to her, some day maybe I can bring these two togeather. My biggest dream is to become a Web designer or a Game developer, and if she could make that, I can do it too."

\section{Teaching materials}

Agüera y Arcas, B. (2005). How PhotoSynth can connect the world's images. TED. https://www.ted.com/talks/blaise aguera y arcas demos photosynth

Arar, R. (2017). How we can teach computers to make sense of our emotions. TED.

https://www.ted.com/talks/raphael arar how we can teach computers to make sense of o ur emotions

Bracy, C. (2013). Why good hackers make good citizens. TED.

https://www.ted.com/talks/catherine bracy why good hackers make good citizens

Buolamwini, J. (2016). How I'm fighting bias in algorithms. TED.

https://www.ted.com/talks/joy buolamwini how $\mathrm{i} \mathrm{m}$ fighting bias in algorithms

Feinberg, D. (2015). The magic ingredient that brings Pixar movies to life. TED.

https://www.ted.com/talks/danielle feinberg the magic ingredient that brings pixar movies to life

el Kaliouby, R. (2015). This app knows how you feel - from the look on your face. TED. https://www.ted.com/talks/rana el kaliouby this app knows how you feel from the look on your face

Lupi, G. (2017). How we can find ourselves in data. TED.

https://www.ted.com/talks/giorgia lupi how we can find ourselves in data

Redmon, J. (2017). How computers learn to recognize objects instantly. TED.

https://www.ted.com/talks/joseph redmon how a computer learns to recognize objects in $\underline{\text { stantly }}$ 


\section{Bibliography}

1. Hüsing, T., Korte, W. B. \& Dashjae E. e-Skills in EuropeTrends and Forecasts for the European ICT Professional and Digital Leadership Labour Markets (2015-2020). Empirica. http://eskillslead.eu/fileadmin/lead/brochure-lead/working_paper__supply_demand_forecast_2015_a.pdf(accessed: 03/20/2020)

2. Eurostat. ICT specialists in employment. (2019) https://ec.europa.eu/eurostat/statisticsexplained/index.php/ICT_specialists_in_employment\#ICT_specialists_by_sex (accessed: 03/20/2020)

3. Nosek, B.A., Smyth F. L., Sriram, N., Lindner, N. M., Devos, T., Ayala, A., Bar-Anan, Y., Bergh, R., Cai, H., Gonsalkorale, K., Kesebir, S., Maliszewski, N., Neto, F., Olli, E., Park, J., Schnabel, K., Shiomura, K., Tulbure, B. T., Wiers, R. W., Greenwald, A. G. National differences in gender-science stereotypes predict national sex differences in science and math achievement. PNAS June 30, 2009106 (26) 10593-10597 (2009). DOI: 10.1073/pnas.0809921106

4. Gál, B. \& Dávid, Á. Azönfejlesztés és a reflektiv pedagógusszemélyiség kialakitásának lehetöségei az. informatika szakos tanárképrésben (in Hungarian). InfoDidact, (2008). https://people.inf.elte.hu/szlavi/InfoDidact08/Manuscripts/GBDA.pdf

5. Pšenáková, I., Heizlerné, B. V., \& Illés, Z. Interaktivitás ą informatikatanításában (in Hungarian). InfoDidact, (2018). https://people.inf.elte.hu/szlavi/InfoDidact18/Manuscripts/PIHBVIZ.pdf

6. Nahalka, I. Azáltalános didaktika és az informatikatanitás didaktikájának egymásra hatása (in Hungarian). InfoDidact, (2009). https://people.inf.elte.hu/szlavi/InfoDidact09/Manuscripts/NI.pdf

7. de Beauvoir, S. A második nem (in Hungarian). Gondolat, (1969).

8. Butler, J. Gender trouble. Routledge, (2007).

9. Bozzi, V. \& Czene, G. Elsikekasztott feminižmus (in Hungarian). Osiris, (2006).

10. Huszár, Á. A nô terei (in Hungarian). L'Harmattan, (2011).

11. Huszár, Á. Bevezetés a gender-nyelvészetbe (in Hungarian). Tinta, (2009).

12. Milestone, K. \& Meyer, A. Gender and popular culture. Polity, (2012).

13. Kovács, M. (Ed.). Társadalmi nemek. Elméleti megköžlitések és kutatási eredmények (in Hungarian). Eötvös kiadó, (2017).

14. Sperling, G. B. \& Winthrop, R. What Works in Girls' Education: Evidence for the World's Best Investment. Brooking Institution, (2016).

15. Kirkup, G. ICT as a tool for enhancing women's education opportunities, and new educational and professional opportunities for women in new technologies. United Nations Division for the Advancement of Women (UNDAW), (2002)

16. OECD. Women in politics (indicator), (2020) DOI: 10.1787/edc3ff4f-en

17. European Union Agency for Fundamental Rights (FRA). Violence against women: An EU-wide survey, (2014). https:// fra.europa.eu/sites/default/files/fra uploads/fra-2014-vaw-surveymain-results-apr14 en.pdf (accessed: 03/30/2020)

Central-European Journal of New Technologies in Research, Education and Practice

Volume 2, Number 2, 2020. 
18. Ehrich, S. A megerôszakolt nem. A nyelv a szexuális erôszakról szóló tárgyalásokon (in Hungarian). In Juhász, V. \&. Kegyesné Szekeres, E. (Eds.), Társadalmi nyelv és nyelvhasználat. Válogatott szemelvények az angol és a német szakirodalomból. (pp. 172194): Szegedi Egyetemi Kiadó, (2011).

19. Bourdieu, P. Masculine domination. Polity, (2001).

20. Global Gender Gap Report. (2017) http://reports.weforum.org/global-gender-gap-report2017/dataexplorer/\#economy=HUN (accessed: 12/20/2019)

21. Marinovich, S., \& Arpad, S. Why hasn't there been a strong women's movement in Hungary?, (1995) DOI: $10.1111 / j .0022-3840.1995 .2902$ 77.x

22. Szlávi, A. The Construction of Gender in Hungarian Discourses. Doctoral dissertation. Eötvös Loránd University (2019).

23. Frehill, L. M. \& McGrath Cohoon, J. Gender and Computing. In: Pearson, Jr. W., Frehill, L. M. \& McNeely, C. L. (Eds.) Advancing Women in Science. An International Perspective (pp. 237-264). Springer, (2015).

24. Mansour, N. \& Wegerif, R. Science Education for Diversity: Theory and Practice. Springer, (2013).

25. Rosser, S. V. Academic Women in STEM Faculty. Palgrave Macmillan, (2017).

26. Lócska, O. D. \& Kovács, Z. 14 to 18-year-old Hungarian high-school students' view of mathematicians appearing in the media - A case study. In: Teaching Mathematics \& Computer Science, 2018/2. pp. 183-194, (2018) DOI: 10.5485/TMCS.2018.0446

27. Crutzen, C. (2005). Questioning Gender in E-learning and its Relation to Computer Science. Space for design, working, and learning. In: Braidotti, R. \& van Baren, A. (eds.) The Making of European Women's Studies Vol. VI. University of Utrecht, pp.40-59.

28. Buolamwini, J., \& Gebru, T. Gender Shades: Intersectional Accuracy Disparities in Commercial Gender Classification. In: Proceedings of Machine Learning Research 81:1-15 (2018). http://proceedings.mlr.press/v81/buolamwini18a/buolamwini18a.pdf

29. Algorithmic Justice League https://www.ajlunited.org/ (accessed: 12/20/2019)

30. Ramirez, F. O. \& Kwak, N. Women's Enrollments in STEM in Higher Education: Cross-National Trends, 1970-2010. In: Pearson, Jr. W., Frehill, L. M. \& McNeely, C. L. (Eds.) Advancing Women in Science. An International Perspective, pp. 9-26. Springer, (2015).

31. Papp, G. \& Keszi, R. A müszaki felsôoktatás a nemek tükrében - különbségek a pályaválasztás és az egyetemi tapasz̧talatok területén. Zárótanulmány. In: Szekeres V. \& Krolify Intézet (eds.) „Ti ezt tényleg komolyan gondoltátok?” Nők és a műszaki felsőoktatás (in Hungarian). Óbudai Egyetem, pp. 214-314, (2013)

32. Bonder, G. Foreword. In: Pearson, Jr. W., Frehill, L. M. \& McNeely, C. L. (Eds.) Advancing Women in Science. An International Perspective pp. v-viii. Springer, (2015).

33. Nagy, B. Háttérben: Kísérlet egy szervezeti nemi rend feltárására (in Hungarian). L'Harmattan, (2014).

34. Lipovits, Á., Háli, A., Kovács, E., Pozsgai, T., \& Gál, B. Ötletek az informatikatanárok képrésébez (in Hungarian). InfoDidact, (2010). https://people.inf.elte.hu/szlavi/InfoDidact10/Manuscripts/LA et al.pdf 
35. Kátai, Z. Multicultural Computer Science Education. InfoDidact (2011). https://people.inf.elte.hu/szlavi/InfoDidact11/Manuscripts/KZ.pdf

36. Margolis, J. \& Fisher, A. Unlocking the Clubhouse. Women in Computing. Cambridge Mass, MIT Press, (2002).

\section{Authors}

\section{SZLÁVI Anna}

Milestone Institute, Budapest, Hungary, e-mail: dr.szlavi@gmail.com

\section{About this document}

Published in:

CENTRAL-EUROPEAN JOURNAL OF NEW TECHNOLOGIES IN RESEARCH, EDUCATION AND PRACTICE

Volume 2, Number 2. 2020

ISSN: 2676-9425 (online)

DOI:

10.36427/CEJNTREP.2.2.472

\section{License}

Copyright C SZLÁVI Anna. 2020

Licensee CENTRAL-EUROPEAN JOURNAL OF NEW TECHNOLOGIES IN RESEARCH, EDUCATION AND PRACTICE, Hungary. This article is an open access article distributed under the terms and conditions of the Creative Commons Attribution (CC-BY) license.

http://creativecommons.org/licenses/by/4.0/

Central-European Journal of New Technologies in Research, Education and Practice

Volume 2, Number 2, 2020. 